\title{
Strength Performance on Different Mix of Cement-Sand Ratio and Sand Condition for Lightweight Foamed Concrete
}

\author{
Yee Ling Lee ${ }^{1 *}$, Cher Siang Tan ${ }^{2}$, Siong Kang Lim ${ }^{1}$, Shahrin Mohammad ${ }^{2}$ and Jee Hock \\ $\operatorname{Lim}^{1}$ \\ ${ }^{1}$ Lee Kong Chian Faculty of Engineering and Science, Universiti Tunku Abdul Rahman, Jalan \\ Sungai Long, Bandar Sungai Long, Cheras, 43000 Kajang, Selangor, Malaysia \\ ${ }^{2}$ School of Civil Engineering, Faculty of Engineering, Universiti Teknologi Malaysia (UTM), 81310 \\ UTM Johor Bahru, Johor, Malaysia.
}

\begin{abstract}
Proper cement-sand ratio and water content can provide excellent consistency and stability for lightweight foamed concrete. The aims of this study are to investigate the comprehensive optimisation design mix of lightweight foamed concrete with different cement-sand ratio and the effect of sand size and admixture towards the consistency and stability of the design mix. Silica fume as admixture was used to verify the improvements in the strength of the foamed concrete. Two types of foamed concrete were prepared, namely SC with sieved sand and UC with unsieved sand used in foamed concrete. Three different cement-sand ratios with different water content were tested for the above two types of foamed concrete for their compressive strength, consistency and stability. The results indicate that foamed concrete using sieved sand gained better consistency and stability. In addition, using silica fume in foamed concrete significantly improved the compressive strength with the highest strength at $27.12 \mathrm{MPa}$ with $1700 \mathrm{~kg} / \mathrm{m}^{3}$ density.
\end{abstract}

\section{Introduction}

The conventional normal weight of concrete with a density ranging of 2000 to $2600 \mathrm{~kg} / \mathrm{m}^{3}$ and strength ranging from 20-60 MPa are well established and is disadvantageous due to its heavy weight. In order to reduce the dead load or the weight of the building, lightweight concrete is introduced to the construction industry. The demand of lightweight concrete in many construction applications has been steadily increasing due to its advantages; lower density and a reducing the size of building foundation [1].

Lightweight foamed concrete (LFC) is a type of cellular concrete produced by the foaming mixture method. Stable voids, which the microscopic air-void was approximately 0.1 to $1.0 \mathrm{~mm}$, are introduced into the cement paste [2]. LFC had a least of $20 \%$ volume of entrained foam in the cement paste [3]. LFC have the advantages, such as low density, high flowability and self-compacting, good in thermal and sound insulation made it popular in

* Corresponding author: yllee@utar.edu.my 
the construction industry for both structural and non-structural purpose [4]. With an appropriate design, lightweight foamed concrete can range from $400 \mathrm{~kg} / \mathrm{m}^{3}$ to $1600 \mathrm{~kg} / \mathrm{m}^{3}$ and it is self-compacting [5]. The typical strength value for lightweight foamed concrete with densities between $800 \mathrm{~kg} / \mathrm{m}^{3}$ to $1000 \mathrm{~kg} / \mathrm{m}^{3}$ is in the range of $1 \mathrm{~N} / \mathrm{mm}^{2}$ to $8 \mathrm{~N} / \mathrm{mm}^{2}$.

It was found that the compressive strength of foamed concrete depended on the amount of sand used and its density. The density depended on the amount of foam introduced into the cement paste. There are a few parameters affecting the strength of LFC; cement-sand ratio, water-cement ratio, curing regime, types of sand and particle size distribution of sand [6]. Optimisation of the LFC design mix was important to ensure the production was sufficiently strong enough for the particular use. Hamidah et al. [6] studied the optimisation of LFC mix with different sand-cement ratios and curing conditions. Four different densities had been investigated in this study. It can be noted that the compressive strength decreased with higher sand-cement ratio, and lower density. Nevertheless, the LFC curing in water had a higher compressive strength, than curing in air.

The strength of LFC was also influenced by the percentage of foam added to the cement paste; it was an inverse function of foam percentage. Adding foam to the cement paste creates pore holes inside the mixture and reduced the density of the LFC. With more foam added into the cement paste, low-density LFC can be obtained. However, the increase of foam dosage was limited to certain percentages. When the dosage limit was surpassed, the foam did not cause any deterioration of density due to foam fraction [7]. Since weight is a structural issue, density is very important in the application of foamed concrete.

Foamed concrete cannot be subjected to any types of compaction or vibration, which may affect the designated density. The flowability and self-compatibility are very important for the characteristics in their fresh-state [8]. Therefore, the objective of this study is to determine the comprehensive optimisation design mix with different cement-sand ratios and the effect of sand size towards the consistency and stability of the design mix. The effect of compressive strength, by adding admixture to the foamed concrete, has also been study so that the proposed foamed concrete mix design can be further used for the proposed lightweight slab system, which had been done for initial testing using normal weight concrete [9-10].

\section{Experimental programme}

\subsection{Material preparation}

Lightweight foamed concrete was produced by using ordinary Portland cement (OPC) as a binder conforming to BS EN 197-1:2011 [11], which was manufactured by Tasek Corporation Berhad, sand, water, silica fume, and synthetic foaming agent.

There are two types of fine aggregate was used in this study. For certain selected mixes, the sand was air-dried and sieved to obtain a particle size small enough for $100 \%$ to pass through a $0.60 \mathrm{~mm}$ sieve opening. Another type of the sand used is unsieved and exposed to natural weather. The sand used was graded with $\mathrm{M}$ class accordance with BS 882: 1992 [12].

A synthetic-based foaming agent and tap water with ratio of 1:30 were used to produce foam for the foamed concrete. Besides that, silica fume was used as an additive base, making up $10 \%$ of the cement weight for selected mixes. 


\subsection{Mix details}

As the LFC aims for structural usage, the minimum compressive strength of $17 \mathrm{MPa}$ at 28 day is required [13]. Based on previous studies [6\&14], in order to obtain compressive strength of $17 \mathrm{MPa}$ or higher at 28-day, the density should be controlled in the range of $1500 \mathrm{~kg} / \mathrm{m}^{3}-1800 \mathrm{~kg} / \mathrm{m}^{3}$. According to the previous study [6], at a density of $1500 \mathrm{~kg} / \mathrm{m}^{3}$, the minimum cement-sand ratio is fixed at $2: 1$. Thus, the initially designed density of the first trial mix was set at $1500 \mathrm{~kg} / \mathrm{m}^{3}$ as it was the lowest value in the density range. There are two Part of lightweight foamed concrete types discussed in this study. For Part 1, three different types of cement-sand ratio namely 3:1, 4:1 and 5:1 designated as SC31, UC31, SC41, UC41, SC51, UC51, respectively, was prepared. The detail of the base mix proportion is based on a $1 \mathrm{~m}^{3}$ volume for each design cement-sand ratio. The designated density was fixed at $1500 \mathrm{~kg} / \mathrm{m}^{3}$ with $\pm 50 \mathrm{~kg} / \mathrm{m}^{3}$, which is tolerable in accordance with industrial practice of foamed concrete [5]. Stable foam was produced by using dry prefoamed method.

On top of the Part 1 trial, Part 2 trial was designed by including silica fume in the two mixes with cement-sand ratios of $3: 1$ and $4: 1$, respectively, in order to enhance the compressive strength of the LFC. In Part 2, four LFC mixes were named as SC31 and SC41, respectively. The addition of silica fume was $10 \%$ of the cement weight. The designated density of LFC in Part 2 had been increased to $1700 \mathrm{~kg} / \mathrm{m}^{3}$ instead of 1500 $\mathrm{kg} / \mathrm{m}^{3}$ in the Part 1. A summary of the details of the experimental works on all Parts of trial mixes are tabulated in Table 1 and 2.

Table 1. The Mix design and experimental work details for Part 1 with density at $1500 \mathrm{~kg} / \mathrm{m}^{3}$

\begin{tabular}{|c|c|c|c|c|c|c|c|}
\hline \multicolumn{6}{|c|}{ MIX PROPORTION } & \multicolumn{2}{|l|}{ Mix Details } \\
\hline $\begin{array}{l}\text { Mix } \\
\text { Designation }\end{array}$ & $\mathbf{w} / \mathbf{c}$ & $\begin{array}{l}\text { Cement } \\
\text { (kg) }\end{array}$ & $\begin{array}{l}\text { Sand } \\
\text { (kg) }\end{array}$ & $\begin{array}{l}\text { Water } \\
\text { (kg) }\end{array}$ & $\begin{array}{l}* \% \\
\text { Foam }\end{array}$ & $\begin{array}{l}\text { Curing } \\
\text { condition }\end{array}$ & $\begin{array}{l}\text { Investigated } \\
\text { properties }\end{array}$ \\
\hline SC31 & 0.46 & 836 & 279 & 385 & 1.8 & \multirow{6}{*}{$\begin{array}{l}\text { Totally } \\
\text { immersed in } \\
\text { water after } \\
\text { 24-hour of } \\
\text { casting, at } \\
\text { temperature } \\
\text { of } 20^{\circ} \mathrm{C} \pm \\
1^{\circ} \mathrm{C}\end{array}$} & \multirow{6}{*}{$\begin{array}{l}\text { 1.Fresh } \\
\text { properties } \\
\text { 2.Compressive } \\
\text { strength test } \\
1\end{array}$} \\
\hline SC41 & 0.46 & 877 & 219 & 403 & 1.4 & & \\
\hline SC51 & 0.46 & 904 & 181 & 416 & 2.1 & & \\
\hline UC31 & 0.27 & 936 & 312 & 253 & 1.6 & & \\
\hline UC41 & 0.35 & 938 & 235 & 328 & 1.9 & & \\
\hline UC51 & 0.33 & 980 & 196 & 323 & 1.8 & & \\
\hline \multicolumn{8}{|c|}{$\begin{array}{l}\text { Note: } \\
S C=\text { Air dry and sieved sand with } 100 \% \text { passing through } 0.60 \mathrm{~mm} \text { used for casting. } \\
\text { UC }=\text { Exposes to natural weather and unsieved sand used for casting.. } \\
* \% \text { Foam used was based on the total weight of cement and sand. }\end{array}$} \\
\hline
\end{tabular}


Table 2. The Mix design and experimental work details for Part 2 with density at $1700 \mathrm{~kg} / \mathrm{m}^{3}$

\begin{tabular}{|c|c|c|c|c|c|c|c|c|}
\hline \multicolumn{7}{|c|}{ MIX PROPORTION } & \multicolumn{2}{|l|}{ Mix Details } \\
\hline $\begin{array}{l}\text { Mix } \\
\text { Designation }\end{array}$ & $\mathbf{w} / \mathbf{c}$ & $\begin{array}{l}\text { Cement } \\
\text { (kg) }\end{array}$ & $\begin{array}{l}\text { Silica } \\
\text { Fume } \\
\text { (kg) }\end{array}$ & $\begin{array}{c}\text { Sand } \\
(\mathrm{kg})\end{array}$ & $\begin{array}{l}\text { Water } \\
(\mathbf{k g})\end{array}$ & $\begin{array}{l}* \% \\
\text { Foam }\end{array}$ & $\begin{array}{l}\text { Curing } \\
\text { condition }\end{array}$ & $\begin{array}{l}\text { Investigation } \\
\text { properties }\end{array}$ \\
\hline $\mathrm{SC} 31$ & 0.47 & 943 & 94.3 & 314 & 443 & 1.3 & \multirow{8}{*}{$\begin{array}{l}\text { Totally } \\
\text { immersed } \\
\text { in water } \\
\text { after } 24 \\
\text { hours of } \\
\text { casting, at } \\
\text { temperature } \\
\text { of } 20^{\circ} \mathrm{C} \pm \\
1{ }^{\circ} \mathrm{C} \\
\end{array}$} & \multirow{8}{*}{$\begin{array}{l}\text { 1. Fresh } \\
\text { properties } \\
2 . \\
\text { Compressive } \\
\text { strength test }\end{array}$} \\
\hline SC31 & 0.49 & 932 & 93.2 & 311 & 457 & 0.8 & & \\
\hline SC31 & 0.51 & 922 & 92.2 & 307 & 470 & 4.4 & & \\
\hline SC31 & 0.53 & 912 & 91.2 & 304 & 483 & 2.9 & & \\
\hline SC41 & 0.47 & 988 & 98.8 & 247 & 464 & 1.6 & & \\
\hline SC41 & 0.49 & 977 & 97.7 & 244 & 479 & 1.0 & & \\
\hline SC41 & 0.51 & 966 & 96.6 & 242 & 493 & 1.5 & & \\
\hline SC41 & 0.53 & 955 & 95.5 & 239 & 506 & 1.0 & & \\
\hline
\end{tabular}

\subsection{Preparation and casting of foamed concrete specimens}

Preparation of lightweight foamed concrete involves three stages. The preparation starts with the production of cement paste. This is followed by the preparation of the stable foam and mixing the foam with the cement paste at the final stage. To prepare the stable foam, the foaming agent is diluted with water and pouring it into the foam generator. Compressed air with a pressure of 5 bar is supplied to the foam generator. The foam is then produced through the nozzle of the generator. Before adding the into the cement paste, the density of the cement paste was determined. This was to make sure the amount of foam that need to be added. Besides that, to check on the workability of the cement paste, flow table test was performed prior adding the foam into the cement paste.

After measuring the required amount of foam, the foam is produced and added into the cement paste to produce lightweight foamed concrete. Foamed concrete was then measured for its fresh density by pouring it into a 1 litre volume container and weighed to ensure that it reached the target density. A $70.7 \mathrm{~mm}$ cubic mould was prepared and produced the cubic specimens. The fresh foamed concrete was left to set and de-moulding it after 24-hour. The cubes were then subjected to the water curing process until reach the respective testing age (7-day and 28-day).

\subsection{Testing method}

\subsubsection{Fresh properties test}

For the fresh properties test, consistency test such as flow table test and inverted slump test were performed to obtain the desired consistency of the mix. The appropriate consistency can optimise the strength of LFC. Flow table test in accordance with the ASTM C1437-13 [15] was performed to determine the consistency of the base mix of LFC. The base mix was filled in the conical mould and compacted evenly 20 times for each layer. The mould was lifted away and subsequently the flow table was rotated for 25 times within 15 seconds. The split value was measured and recorded by taking an average measurement values from its orthogonal directions. 
As for the inverted slump test, the test was performed in accordance with BS EN 12350-8:2010 [16]. After freshly mixing the cement paste with the stable foam, foamed concrete was filled into the inverted slump flow cone without applied any compaction or vibration. The cone is then raised vertically and let the foamed concrete spread freely. The spread diameter values were measured by taking an average measurement in an orthogonal direction.

\subsubsection{Compressive strength}

The compressive strength test was performed in accordance with BS EN 12390-3 [17]. The constant pace rate of $0.1 \mathrm{kN} / \mathrm{s}$ was applied during testing the $70.7 \mathrm{~mm}$ cubic specimens. An average compressive strength was obtained after crushing the three crush cubic specimens.

\section{Results and discussions}

\subsection{Part 1}

For Part 1, the consistency and stability of the fresh mixed foamed concrete is represented by measuring the fresh density against the target density and the hardened density, respectively. The mix is considered consistence and stable when the density ratio was kept nearly to unity [8] without any segregation or bleeding occurring during the test. In addition, for a stable mix, the produced hardened foamed concrete was supposed to be in the range of $\pm 50 \mathrm{~kg} / \mathrm{m}^{3}$ corresponding to the target density, which is $1500 \mathrm{~kg} / \mathrm{m}^{3}$, as mentioned before [5].

Because the lightweight foamed concrete mix is initially planned for large-volume casting, large production of lightweight foamed concrete is required and $0.60 \mathrm{~mm}$ sieve sand may not be practical. Hence in Part 1, the mix was divided into two parts with the same materials but different sand grades. There are two types of sand used; sand which was air dried and sieved passed through $0.60 \mathrm{~mm}$ and the sand directly obtained from the bulk and exposed to natural weather. Sand obtained from the bulk was neither dried nor sieved. From the comparison between two types of sand, it can be seen that the water-cement ratio for sieved sand foamed concrete is higher than the foamed concrete with unsieved sand. The smaller particle size of air-dried sieved sand created a higher surface area, allowing for more water to be absorbed and increase inter-particle lubrication. This will result in a higher fluidity and better workability [18]. In this study, the spread value for sieved sand foamed concrete were mostly higher than that of the raw sand foamed concrete as shown in Table 3, thus proving the statement. 
Table 3. Part 1 result based on its consistency and stability

\begin{tabular}{|c|c|c|c|c|c|}
\hline Specimens & $\mathbf{W} / \mathbf{C}$ & Consistency & Stability & $\begin{array}{c}\text { Inverted } \\
\text { slump cone } \\
\text { spread } \\
\text { value } \\
(\mathrm{mm})\end{array}$ & $\begin{array}{l}\text { Performance } \\
\text { Index }\end{array}$ \\
\hline SC31 & 0.46 & 0.93 & 0.96 & 450 & 4.81 \\
\hline SC41 & 0.46 & 0.99 & 1.01 & 490 & 5.80 \\
\hline SC51 & 0.46 & 0.87 & 0.94 & 490 & 4.37 \\
\hline UC31 & 0.27 & 0.89 & 0.79 & 410 & 3.37 \\
\hline UC41 & 0.35 & 0.89 & 0.89 & 470 & 4.58 \\
\hline UC51 & 0.33 & 0.92 & 0.89 & 540 & 6.22 \\
\hline \multicolumn{6}{|c|}{ Consistency $=\frac{\text { Fresh density }}{\text { Target density }}$ Stability $=\frac{\text { Fresh density }}{\text { hardened density }}$} \\
\hline $\begin{array}{l}\text { Performance In } \\
\text { Inverted slum }\end{array}$ & Compre & $\begin{array}{l}\text { e strength } \times 1000 \mathrm{~kg} \\
\text { dened density } \\
\text { tlue }=\text { average a }\end{array}$ & & & \\
\hline
\end{tabular}

Moreover, the air-dried sieved sand has a better water absorption than the unsieved sand, as shown in Table 3, where the water required for air-dried and sieved sand was $52.8 \%, 23.2 \%$ and $28.8 \%$ higher for SC31, SC41 and SC51, respectively, in order to achieve the similar spread value with raw sand. Unsieved sand exposed to natural weather has higher moisture content than the air-dried sand. The existing moisture in the unsieved sand influences the water content for casting and hence giving a lower water-cement ratio compared to the sieved sand foam concrete.

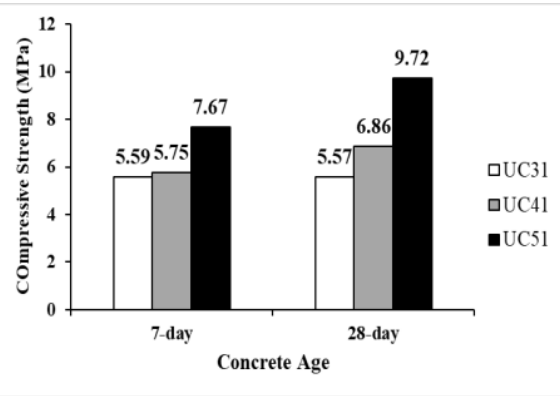

(a) unsieved sand foamed concrete

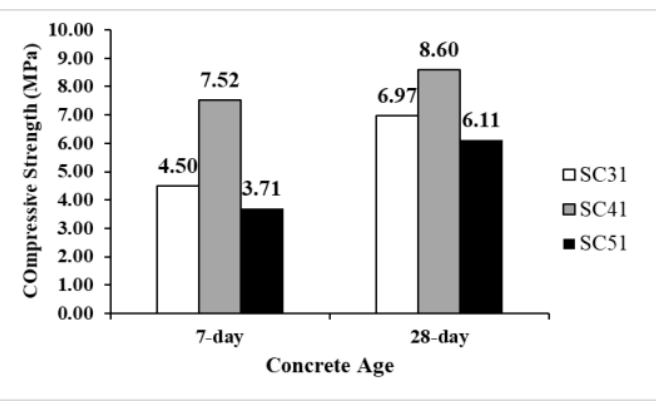

(b) sieved sand foamed concrete

Fig.1. Compressive strength development

Fig. 1 shows the compressive strength development for both unsieved sand and sieved sand foamed concrete. UC 51 obtained the highest 28 -day compressive strength, which is 9.722 $\mathrm{MPa}$. It increased about $26.8 \%$ from the 7 -day compressive strength. From the hydration process, the most important cementing component for hardening and strength development is calcium-silicates-hydrate $(\mathrm{C}-\mathrm{S}-\mathrm{H})$ gel. Higher cement content in foamed concrete, production of $\mathrm{C}-\mathrm{S}-\mathrm{H}$ gel is more and can impose additional loading. Overall, referring to Fig. 1, it can be seen that the compressive strength increased with increasing the cement content except for specimens SC51. Mostly the SC samples have higher compressive strengths than UC specimens with the respective cement-sand ratio. Sieved 
sand as the filler have smaller particle size with a higher surface area and believed that have better force transfer from sand-sand interaction. However, for SC 51, it has a lower strength than UC51, SC 31 and SC 41. The decrease in strength may be due to excessive cement content, it will make the specimens very brittle since the cement particles cannot transfer normal force contact. This can be verified in Table 1, the proportion of sand for SC51 is the lowest among all the UC and SC specimens. This is the reason why SC 51 possessed a lower strength than that of UC 51, SC 31 and SC 41. The improper combination of the high cement content with the least filler affected their interaction and force sharing.

From the results, it is concluded that UC51 achieved the highest compressive strength with performance index of 6.22 . However, its consistency and stability are undesirable. Specimen SC41 demonstrates better consistency and stability within 1\%, and performance index of 5.80, rank at the second among the six specimens.

\subsection{Part 2}

The results in Part 1 showed that the highest cement to sand ratio of 5:1 had a lowered strength performance compared to that of $3: 1$ and $4: 1$, thus the cement-sand ratio, 5:1, was excluded in the Part 2 trial. From the results in Part 1, the compressive strength is only suitable for filling voids and trench reinforcement, which can be disregarded for the structural section. In order to improve the strength of the foamed concrete, experimental work on Part 2 had been taken out by increasing control density by $1700 \mathrm{~kg} / \mathrm{m}^{3}$ and adding silica fume.

Table 4. Part 2 result based on its consistency and stability

\begin{tabular}{|c|c|c|c|c|c|}
\hline Specimen & $\mathbf{w} / \mathbf{c}$ & Consistency & Stability & $\begin{array}{l}\text { Inverted } \\
\text { slump cone } \\
\text { spread } \\
\text { value } \\
(\mathrm{mm}) \\
\end{array}$ & $\begin{array}{l}\text { Performance } \\
\text { Index }\end{array}$ \\
\hline $\mathrm{SC} 31$ & 0.47 & 0.96 & 0.92 & 470 & 13.89 \\
\hline SC31 & 0.49 & 0.99 & 0.94 & 490 & $\begin{array}{l}14.77 \\
\end{array}$ \\
\hline $\mathrm{SC} 31$ & 0.51 & 0.90 & 0.95 & 500 & 7.42 \\
\hline $\mathrm{SC} 31$ & 0.53 & 0.86 & 0.92 & 510 & 5.66 \\
\hline $\mathrm{SC} 41$ & 0.47 & 0.89 & 0.87 & 470 & 12.02 \\
\hline SC41 & 0.49 & 0.96 & 0.91 & 490 & 14.03 \\
\hline SC41 & 0.51 & 0.96 & 0.97 & 500 & 10.32 \\
\hline SC41 & 0.53 & 0.91 & 0.97 & 500 & 10.69 \\
\hline \multicolumn{6}{|c|}{ Consistency $=\frac{\text { Fresh density }}{\text { Target density }} ;$ Stability $=\frac{\text { Fresh density }}{\text { hardened density }}$} \\
\hline \multicolumn{6}{|c|}{ Performance Index $=$ Compressive strength $\times 1000 \mathrm{~kg} / \mathrm{m}^{3}$} \\
\hline
\end{tabular}

By referring to Table 4, which shows the results of the consistency and stability for the foamed concrete specimens, the performance index, which is 28-day compressive strength to unit density, increases with the addition of silica fume and density. Among the results in Part 2, SC 31, with water-cement ratio 0.53, possessed the lowest values of consistency and performance index, which are 0.86 and 5.66 respectively. The excessive foam added in SC 31 may cause the largest deviation between the designated density and actual fresh density. 
In addition, the lowest actual density of SC 31 had sharply decreased its strength, consequently causing the SC 31 to obtain the lowest performance index.

For the stability, SC41 with water-cement ratio 0.47 obtained the lowest stability of 0.87. The lowest water content in Part 2 made the SC 41 mix design drier and stiffer compared to others. The dry and stiff mix causes the breaking of air bubbles, consequently affecting the unity of its stability value. Lower water content can also affect the workability of the foamed concrete. The lowest spread diameter value of SC 41 and SC 31 with a water-cement ratio of 0.47 also verified that the mixes were the driest among the mixes in Part 2. Among all the samples in Part 2, SC31, with water-cement ratio 0.49, exhibit the highest performance index, which is 14.77 . Both the consistency and stability of SC 31 were acceptable, where the differences were less than $10 \%$.

Fig. 2 show the compressive strength development for sieved sand foamed concrete with respective cement-sand ratio at a constant density of $1700 \mathrm{~kg} / \mathrm{m}^{3}$. The strength development increased from 7-day concrete age to 28-day concrete age for all the samples. For SC 31 and SC 41, both obtained the highest compressive strength for its own mix design respectively at a water-cement ratio 0.49 . The strengths achieved were $27.12 \mathrm{MPa}$ and 25.32 MPa respectively. SC 31 obtained the highest strength among all the samples in Part 2, which is $7.1 \%$ higher than that of the best for SC 41 mix. After the water-cement of 0.49 , both mixes for SC 31 and SC 41 experienced a drop in compressive strength at watercement ratio 0.51 and 0.53 . This may due to higher water content in the mixes and cause the segregation happened.

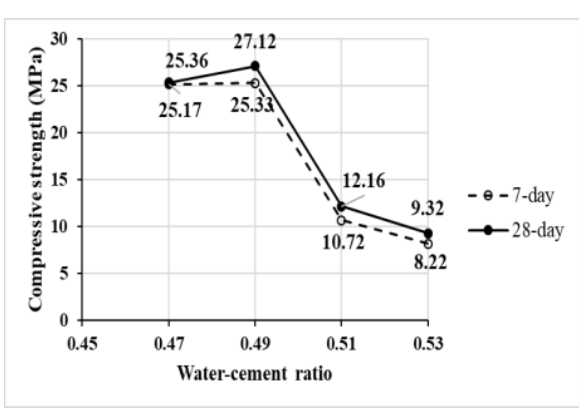

(a) SC 31 mix's

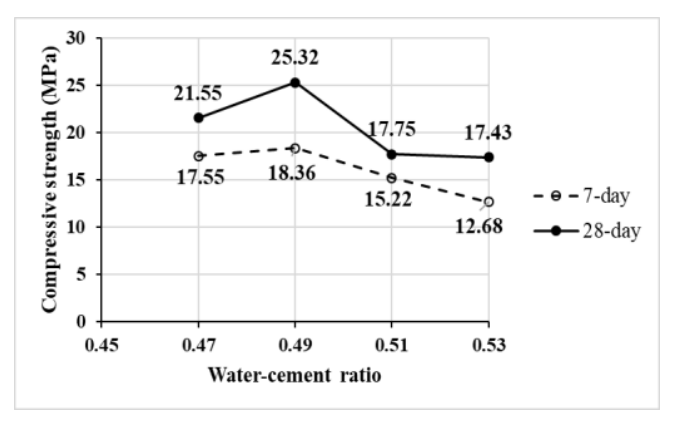

(b) SC 41 mix's

Fig.2. Compressive strength development at various w/c ratios

Silica fume, which is approximately 100 times smaller than cement particles, and contains high reactive silica content, was used to improve the strength of foamed concrete. The micro-fine particle size of silica fume possesses huge surface areas. Therefore, high water-cement ratios are needed for silica fume mix in order to achieve proper consistency of cement paste. This can explain why the water-cement used in Part 2 was higher than that of Part 1. The high pozzolanic activity between the reactive silica in silica fume and calcium hydroxide $(\mathrm{CH})$ by cement hydration formed extra $\mathrm{C}-\mathrm{S}-\mathrm{H}$ gels and thus the microstructure of the LFCs in Part 2 were denser. This consequently enhanced its 28-day compressive strength sharply, where the highest strength of $27.12 \mathrm{MPa}$ had been achieved. The results indicated that the LFC in Part 2 has the potential to be used in structural application. In conclusion, based on the results from 2 Part of trials, the optimal mix was with cement-sand ratio of 3:1 and water-cement sand ratio of 0.49 . 


\section{Conclusions}

This study exhibits the design mix of lightweight foamed concrete with different cementsand ratios, the effect of sand size and the effect of admixture towards the consistency, stability and strength of the design mix. Several conclusions related to the objectives of this study can be drawn from the laboratory investigations.

1. Lightweight foamed concrete with a density of $1500 \mathrm{~kg} / \mathrm{m}^{3}$ achieve 28-day design strength between $5.57 \mathrm{MPa}$ to $9.72 \mathrm{MPa}$.

2. Lightweight foamed concrete with a density $1700 \mathrm{~kg} / \mathrm{m}^{3}$ and $10 \%$ silica fume achieve 28-day design strength of 9.32 MPa to $27.12 \mathrm{MPa}$.

3. Provision of sieved sand as filler provide better consistency and stability of the designed density compared to un-sieved sand.

4. There is a trend in strength increment in-line with the increase of cement contents, but the strength drops at cement: sand ratio of $5: 1$.

5. Admixture of silica fume increases the performance index of lightweight foamed concrete. However, further investigation is needed to identify the optimum percentage of admixture.

6. Finer sand requires higher water-cement ratio for the desired workability of fresh concrete. Although low water-cement ratio may result in higher compressive strength of lightweight foamed concrete, it decreases the workability of fresh concrete and stability of the designed density.

7. It is noticed that the highest 28-day compressive strength obtained from both Part is 27.12 MPa, which demonstrates a potential for the structural use of lightweight foamed concrete. However, the mechanical properties of the lightweight foamed concrete need to be further investigated for actual structural usage.

The research works in this paper has been supported by the Universiti Teknologi Malaysia, UTM Research Management Centre (Grants Vot 4F647 and Vot 10H05), Universiti Tunku Abdul Rahman Research Fund (6200/LL4), and the Ministry of Higher Education (MOHE). The authors also express sincere gratitude to technicians from both the Laboratory of Structures and Materials, the Faculty of Civil Engineering and Civil Engineering Laboratory, Lee Kong Chian Faculty of Engineering and Science.

\section{References}

1. M. J. Shannag, Constr Build Mater, 25(2), 658-662 (2011)

2. F. H. Fouad, Cellular concrete, 56-569 (2006)

3. H. Awang, M. A. O. Mydin, A. F. Roslan, Advances in Applied Science Research, 3(5), 3326-3338 (2012)

4. S. K. Lim, C. S. Tan, O. Y. Lim, Y. L. Lee, Constr Build Mater, 46, 39-47 (2013)

5. M. R. Jones, A. McCarthy, R. K. Dhir, WRAP Research Report (2005)

6. M. S. Hamidah, I. Azmi, M. R. A. Ruslan, K. Kartini, Use of foamed concrete in construction, 37-44 (2005).

7. H. S. Lee, M. A. Ismail, Y. J. Woo, T. B. Min, H. K. Choi, Materials, 7(6), 4536-4554 (2014)

8. E. K. K. Nambiar, K. Ramamurthy, J Mater Civil Eng, 20(2), 111-117 (2008)

9. Y. L. Lee, C. S. Tan, Y. H. Lee, S. Mohammad, P. N. Shek, Proceeding of 8th Asia Pacific Structural Enginneering and Construction Conference (APSEC 2012) and 1st International Conference on Civil Engineering Rearch (ICCER 2012), 162-166 (2012) 
10. C. S. Tan, Y. L. Lee, S. Mohammad, S. K. Lim, Y. H. Lee, J. H. Lim, Jurnal Teknologi (Sciences \& Engineering), 74(4), 39-44 (2015)

11. BSI, BS EN 197-1:2011: Composition, specifications and conformity criteria for common cements (2011)

12. BSI, BS 882:1992: Specification for aggregates from natural sources for concrete (1992)

13. M. S. Shetty, Concrete technology: theory and practice (2006)

14. E. P. Kearsley, Concrete in the service of mankind appropriate concrete technology, 232-242 (2006)

15. ASTM, ASTM C1437-13: Standard test method for flow of hydraulic cement mortar (2013)

16. BSI, BS EN 12350-8:2010: Testing fresh concrete- part 8: Self-compacting concreteslump-flow test (2010)

17. BSI, BS EN 12390-3:2009: Testing hardened concrete -part 3: compressive strength of test specimens (2009)

18. E. Smith, Advances of cement and concrete technology: properties and applications (2012) 